\title{
PERAN INSTITUSI LOKAL DALAM KEGIATAN PENGEMBANGAN MASYARAKAT: KASUS PUNGGAWA RATU PASUNDAN DALAM PROGRAM DESA WISATA DI DESA SUKARATU KECAMATAN GEKBRONG KABUPATEN CIANJUR
}

\author{
OLEH \\ RUDI SAPRUDIN DARWIS ${ }^{1}$, RISNA RESNAWATY ${ }^{2}$, MAULANA IRFAN $^{3}$, APEP RISMAN ${ }^{4}$ \\ ${ }^{1}$ Staf Pengajar Departemen Kesejahteraan Sosial Universitas Padjadjaran \\ ${ }^{2}$ Staf Pengajar Departemen Kesejahteraan Sosial Universitas Padjadjaran \\ ${ }^{3}$ Staf Pengajar Departemen Kesejahteraan Sosial Universitas Padjadjaran \\ ${ }^{4}$ Pekerja Sosial pada Yayasan Sosial
}

(rudi.darwis@unpad.ac.id; risna.resnawaty@unpad.ac.id; sangirfan@gmail.com; apeprisman@yahoo.co.id)

\begin{abstract}
Abstrak
Pengembangan masyarakat merupakan suatu aktivitas yang direncanakan guna meningkatkan taraf hidup masyarakat melalui program-program yang mampu mengembangkan potensi yang dimiliki dan menggunakan institusi lokal sebagai wadah aktivitas kolektifnya. Penelitian ini ditujukan untuk menggambarkan peran institusi lokal dalam program Desa Wisata di Desa Sukaratu Kecamatan Gekbrong Kabupaten Bandung yang telah mampu menarik partisipasi aktif masyarakat untuk menjadi pelaku utama dalam pengelolaan kegiatan wisata. Pendekatan yang digunakan dalam studi ini adalah pendekatan kualitatif dengan teknik studi kasus. Adapun kasus yang dijadikan subyek studi adalah kasus Punggawa Ratu Pasundan (PRP) sebagai institusi lokal yang dibentuk dalam program desa wisata di Desa Sukaratu, Kecamatan Gekbrong, Kabupaten Cianjur. Gambaran mengenai peranan institusi lokal dalam pengembangan masyarakat akan dideskripsikan melalui empat peranan yang dilakukan PRP dalam aktivitas pengembangan desa wisata di Desa Sukaratu, yaitu fasilitatif, mediasi, penyampai informasi, dan pendayagunaan gotong royong. Hasil penelitian menunjukan peran fasilitatif dilaksakan oleh PRP dalam menjaring berbagai aspirasi masyarakat dan anggotanya. Peran mediasi dilakukan oleh PRP dalam ranah penyelesaian konflik-konflik yang terjadi didalam organisasi. Peran PRP sebagai penyampai informasi sering dilakukan dalam rapat mingguan guna terus menjaga konsisitensi organisasi dalam mengedukasi masyarakat. Peran terakhir adalah peran PRP dalam mendayagunakan gotong royong masyarakat, peran ini dilakukan dengan mewadahi kegiatan-kegiatan gotong royong masyarakat dan menyalurkannya melalui kegiatan-kegiatan pembangunan yang menyangkut kepentingan umum. Namun suksesi kepengurusan yang tertundatunda, hilangnya sosok tokoh masyarakat yang menjadi salah satu penggerak, dan kurangnya dukungan dari pemerintah setempat menyebabkan vakumnya kepengurusan PRP, sehingga kegiatannya agak tersendat. Atas dasar hasil studi ini maka direkomendasikan bahwa untuk
\end{abstract}


merealisasikan suksesi organisasi oleh masyarakat secara independen dan mandiri agar kegiatan pegelolaan wisata Desa Sukaratu dapat berlanjut secara optimal.

Kata kunci: desa wisata, organisasi lokal, peran, pengembangan masyarakat

\section{Pendahuluan}

Kajian mengenai pengembangan masyarakat dalam kaitannya dengan masyarakat lokal sudah banyak dilakukan, namun kajian-kajian tersebut hanya membahas beberapa aspek yang ada pada masyarakat lokal dan dikaji secara parsial tidak dalam kaitan dengan aspek-aspek lokal pengembangan masyarakat. Seperti kajian yang dilakukan oleh Mowbray (2011), Buccus, Hemson, Hicks, dan Piper (2008) serta McKinlay (2006) membahas tentang kedudukan pemerintah lokal yang yang cukup penting dalam mendorong dan menjamin adanya proses partsipasi masyarakat dalam pengembangan masyarakat pada berbagai tingkat kegiatan. Kajian mengenai partisipasi masyarakat merupakan kajian yang paling banyak dibahas dalam berbagai issue. Seperti kajian dari Yen dan Luong (2008) menunjukkan bahwa partisipasi masyarakat dalam perencanaan pengembangan masyarakat membutuhkan kepemimpinan yang dapat mendorong efektivitas partisipasi.

Terkait dengan hal tersebut, Botes dan van Rensburg (2000) serta Eversole (2012) menggambarkan partisipasi sebagai proses yang kompleks sehingga membutuhkan kemampuan untuk menterjemahkan berbagai aspek internal masyarakat maupun eksternal serta mengintegrasikannya bersama pengetahuan masyarakat dan kelembagaan masyarakat dalam mengembangkan partisipasi. Dalam implementasinya, hasil kajian Marfo (2008) menguraikan tentang pentingnya pelembagaan partisipasi serta sensitivitas untuk membuka peluang bagi paritisipasi masyarakat, serta fleksibilitas untuk mengakomodasi dinamika antar berbagai faktor yang mempengaruhi partisipasi dalam proses pengembangan masyarakat. Namun kajian ini tidak banyak menjelaskan aspek-aspek lainnya dalam proses pengembangan masyarakat.

Pengkajian mengenai aspek-aspek lokal (termasuk di dalamnya institusi lokal) pada komunitas dalam konteks proses pengembangan masyarakat dapat menjelaskan kedudukan setiap aspek lokal pada masyarakat dalam pencapaian tujuan pengembangan masyarakat. Pemahaman mengenai aspekaspek lokal masyarakat sangat penting bagi pekerjaan sosial karena akan mempengaruhi tindakan yang akan dilakukan dalam proses intervensi melalui pendekatan pengembangan masyarakat. Oleh karena itu, berkaitan dengan pengembangan masyarakat sebagai metode, dalam penelitian ini akan dikaji peranan institusi/lembaga lokal dalam pengembangan masyarakat masyarakat desa.

Peranan insitusi lokal tersebut dilakukan dalam upaya pengembangan potensi desa wisata sebagai salah satu alternatif bentuk pengembangan masyarakat desa. Kementrian Kebudayaan dan Pariwisata mencatat saat ini di Indonesia terdapat 987 desa wisata, padahal Tahun 2009 yang hanya 
tercatat 144 desa. $^{38}$ Pengembangan desa wisata memiliki manfaat selain terhadap peningkatan ekonomi masyarakat juga dapat menjaga kelestarian lingkungan (Soemarno, 2010) ${ }^{39}$.

Sebagai salah satu desa yang mengembangkan program desa wisata, Desa Sukaratu yang berada di Kecamatan Gekbrong Kabupaten Cianjur membentuk kelembagaan lokal yang diberikan kewenangan untuk melakukan pengembangan potensi desa wisata yaitu Punggawa Ratu Pasundan (PRP). Desa Sukaratu termasuk desa yang dibangun atas dasar insiatif warga masyarakat disana yang melihat potensi keanekaragaman budaya dan kesenian yang hidup dan berkembang dalam kehidupan masyarakat. PRP yang berada di desa Sukaratu merupakan salah satu desa yang sekarang sedang berkembang menjadi desa wisata yang berbasis pengembangan potensi budaya dan kesenian lokal.

Karakteristik pengembangan desa Sukaratu sebagai desa wisata oleh PRP dibangun berdasarkan potensi dan kondisi lokal. Hal ini yang mendukung untuk terjaganya aspek lingkungan hidup; ini sebagai hasil dari penerapan pengembangan masyarakat yang berbasis lokal. Oleh karena itu, penelitian ini akan mengkaji bagaimanakah peranan PRP sebagai institusi lokal pengembangan masyarakat dalam pengembangan Desa Wisata.

\section{Metode Penelitian}

Penelitian mengenai Peran Intitusi Lokal Dalam Kegiatan Pengembangan Masyarakat Di Desa Sukaratu, Kecamatan Gekbrong, Kabupaten Cianjur bermaksud untuk mengkaji

\footnotetext{
${ }^{38}$ melalui

http://www.suaramerdeka.com/v1/index.php/read/n ews/2012/02/10/109131/ 978-Desa-Wisata-Tumbuhdi-Indonesia) [30 jan 2014]
}

peran intitusi lokal dalam kegiatan pengembangan masyarakat untuk peningkatan kesejahteraan masyarakat di suatu wilayah tertentu (locality). Untuk mendapatkan gambaran proses pengembangan masyarakat secara sistematik, faktual dan akurat, penelitian ini menggunakan metode deskriptif. Metode ini digunakan untuk menganalisis secara mendalam fenomena sosial yang ada pada masyarakat dalam proses pengembangan masyarakat.

Pendekatan penelitian ini menggunakan pendekatan kualitatif karena peneliti bermaksud untuk memperoleh gambaran yang mendalam mengenai peran intitusi lokal dalam kegiatan pengembangan masyarakat pada program pengembangan Desa Wisata di lokasi penelitian. Untuk mendapatkan informasi yang utuh mengenai peran intitusi lokal dalam kegiatan pengembangan masyarakat, maka teknik penelitian yang digunakan dalam penelitian ini adalah teknik studi kasus, yaitu suatu cara pengumpulan data dari beberapa informan yang terkait langsung pada penelitian ini. Yin (dalam Creswell 2002: 11) mengemukakan bahwa studi kasus adalah penelitian yang menggali kesatuan atau fenomena tunggal (kasus) yang dibatasi oleh waktu dan aktivitas (program, kejadian, proses, institusi, atau kelompok sosial) dan mengumpulkan informasi rinci dengan menggunakan berbagai prosedur pengumpulan data selama periode waktu tertentu.

Adapun kasus yang dijadikan subyek dalam penelitian ini adalah PRP yang merupakan institusi lokal yang sengaja dibentuk untuk diberi kewenangan mengelola kegiatan desa wisata. Data dihimpun dengan

\footnotetext{
${ }^{39}$ melalui marno.lecture.ub.ac.id/files/2012/01/Desawisata.doc [30/ jan 2014]
} 
menggunakan teknik wawancara dan observasi terhadap situsi yang berlangsung dalam masyarakat. Wawancara dilakukan terhadap pihak-pihak yang mengetahui kondisi PRP dan berbagai kegiatan yang telah dilakukan dalam rangka program desa wisata, baik itu dari kalangan masyarakat umum maupun tokohtokoh masyarakat. Sumber data utama dalam penelitian ini adalah community development worker (CD worker) dalam program desa wisata sebagai pihak yang paling memahami dinamika sosial politik masyarakat di Desa Sukaratu pada pelaksanaan program desa wisata. Data yang diperoleh dari berbagai sumber dan menggunakan berbagai teknik selanjutnya dilakukan cross check satu sama lain sehingga menghasilkan data yang valid dan reliable. Analisis data dilakukan meliputi tiga komponen analisis dari Miles dan Huberman (1985) yaitu: reduksi data, sajian data, dan penarikan kesimpulan. Sesuai dengan tujuan penelitian, selanjutnya data dianalisis berdasarkan empat peran institusi lokal, yaitu peran fasilitatif, mediasi, pemberi informasi, dan mendayagunakan gotong royong masyarakat dalam kegiatan pengembangan masyarakat di Desa Sukaratu, sehingga pada akhirnya dapat menggambarkan berbagai peran yang dilakukan oleh PRP dalam mengelola kegiatan wisata yang diselenggarakan di Desa Sukaratu.

\section{Perkembangan dan Kondisi Punggawa Ratu Pasundan}

PRP merupakan institusi lokal pengelola program desa wisata yang di selenggarakan di Desa Sukaratu Kabupaten Cianjur. Lembaga ini dibentuk oleh masyarakat karena adanya dorongan kebutuhan terhadap sebuah kelompok yang bisa mewadahi berbagai potensi wisata yang dimiliki masyarakat Sukaratu dan mengelola kegiatan wisata yang ada di Sukaratu. PRP sendiri merupakan kepedekatan kata dari Kampung (desa) pembelajaran dan pemberdayaan bagi keluarga dan siswa (generasi penerus) di Sukaratu tatar pasundan (sunda). PRP diselenggarakan atas dasar kepercayaan dari berbagai elmen yang ada di masyarakat, baik elmen pemerintah, tokoh masyarakat maupun masyarakat biasa pada umumnya. Berbagai elemen inilah yang kemudian menjadi pengurus dan pengelola wisata desa yang di selenggarakan di Desa Sukaratu.

Pembentukan lembaga pengelola desa wisata ini juga sebagai dorongan dari PNPM Mandiri Pariwisata yang mengharuskan adanya lembaga lokal yang dibentuk untuk mengelola program desa wisata secara khusus. Dalam konteks Program PNPM Mandiri Pariwisata, istilah Punggawa Ratu Pasundan yang merupakan sebutan untuk program desa wisata, digunakan juga sebagai sebutan untuk Lembaga Pengelola Kegiatan (LPK) yang dipersyaratkan dalam PNPM Mandiri Pariwisata untuk mendapatkan bantuan program.

\section{Program PNPM Mandiri Pariwisata ini} masuk ke Desa Sukaratu setelah masyarakat Desa Sukaratu mengembangkan aktivitas wisata di desanya secara mandiri. Pengembangan Desa Sukaratu sebagai desa wisata bermula dari dinobatkannya Desa Sukaratu sebagai Desa Budaya yang meraih juara pada lomba desa di tingkat Provinsi Jawa Barat Tahun 2010. Keikutsertaan Desa Sukaratu dalam kejuaraan ditingkat Provinsi memberikan dampak yang cukup baik terhadap kondisi sarana prasarana lingkungan di Desa Sukaratu. Pembangunan yang cukup positif dapat dilihat secara langsung dalam penataan lingkungan desa, jalan-jalan diperbaiki dan dibersikan oleh masyarakat 
secara gotongroyong, hal inilah yang kemudian memunculkan rasa nyaman bagi siapa saja yang berkunjung ke Desa Sukaratu.

Kondisi lingkungan yang bersih dan asri ini memberikan dorongan terhadap pemikiran masyarakat untuk kemudian menjadikan Desa Sukaratu sebagai desa wisata. Pemikiran warga masyarakat Desa Sukaratu untuk menjadikan desanya sebagai Desa Wisata tidaklah berlebihan, karena secara kepemilikan aset Desa Sukaratu menyimpan berbagai potensi yang bisa dikembangkan. Diantara potensi wisata yang dapat dikembangkan di Sukaratu ini adalah banyaknya situs peninggalan bersejarah yang bisa dikembangkan menjadi wisata sejarah, hamparan sawah dan perkebunan teh pun dapat dikembangkan menjadi wisata alam serta ragam kegiatan kesenian dan permainan rakyat yang masih dilestarikan hingga kini.

Para penggagas desa wisata berpikiran bahwa kondisi lingkungan yang baik ini akan dapat terjaga dan mejadi semakin baik jika dimanfaatkan sebagai sumber untuk meningkatkan kesejahteraan masyarakat. Landasan pemikiran inilah yang kemudian mendorong masyarakat untuk membangun sebuah institusi/lembaga yang mampu mewadahi dan mengembangkan berbagai macam potensi yang dimiliki masyarakat Sukaratu baik alam mapun potensi sumberdaya manusianya. Keinginan masyarakat untuk membangun institusi ini mendapat ternyata mendapat sambutan cukup baik dari tokoh masyarakat dan pemerintah desa setempat, sehingga dalam pembentukan institusi ini tidak banyak mendapat hambatan yang berarti.

Pada perkembangan selanjutnya PRP ini kemudian mulai menjelma menjadi institusi yang sangat dikenal masyarakat. Berbagai kegiatan pertemuan, pelatihan dan study banding diselenggarakan untuk terus menstimulus ide-ide kreatif masyarakat dalam pengelolaan potensi desa menjadi suatu yang layak untuk ditampilkan dalam kegiatan wisata di Sukaratu. Kesuksesan menjadi penyelenggara perkemahan tingkat international menjadi salah satu bukti bahwa PRP dan masyarakat yang tergabung di dalamnya telah mampu bekerjasama, berkolaborasi dan menjadi tuan rumah yang baik bagi para peserta perkemahan yang mempunyai latarbelakang budaya dan negara yang berbeda.

Namun kesuksesan PRP sebagai wadah pengelolaan wisata Sukaratu tidak bertahan lama. Hal ini diakibatkan karena setelah kegiatan perkemahan internasional tersebut tim PRP kehilangan salah satu tokoh penggerak partisipasi masyarakatnya. Beliau adalah Abah Oni, seorang tokoh masyarakat sekaligus ketua RT di dusun Cibeleng. Hilangnya tokoh ini cukup mempengaruhi aktifitas kegiatan wisata yang ada di Sukaratu, kerena tidak adanya local leader yang mampu menggantikan perannya sebagai penggerak partisipasi dalam masyarakat.

Selain kehilangan Abah Oni sebagai salah satu tokohnya, PRP juga terhambat oleh minimnya sumberdaya manusia yang bisa memimpin organisasi PRP ini. Masyarakat tidak memiliki tokoh lagi yang bisa dikatakan mampu setelah beberapa diantaranya mengundurkan diri dan karena kalah dalam pemilihan kepala desa, sehingga pada akhirnya lebih memilih bekerja di kota. Adapun sumberdaya manusia yang lain belum memiliki kepercayaan diri untuk mempin organisasi ini, diperparah lagi dengan kurangnya dukungan dari pemerintahan desa yang baru, Surat Keputusan kepala desa untuk mengesahkan pengurus PRP sampai sekarang belum diterbitkan, sehingga hal itu membuat kepengurusan di dalam PRP menjadi vacum. 
Dampak lain yang timbul dari belum terbit kembali surat keputusan ini adalah berkurangnya semangat dari para anggota untuk kembali lagi bergerak mempromosikan kegiatan wisata di Sukaratu. Walaupun demikian, kegiatan-kegiatan yang dilakukan oleh kelompok penggerak pariwisata yang tergabung didalam PRP masih dapat dijumpai dan diminta untuk melayani berbagai macam kebutuhan masyarakat, baik hiburan ataupun kebutuhan lainnya. Kelompok kompepar ini tetap hidup meskipun kepengurusan PRP vacuum karena kegiatan yang mereka lakukan adalah bagian dari kehidupan mereka yang diandalkan untuk memenuhi kebutuhan hidupnya sehari-hari

\section{a. Keanggotaan}

Sifat keanggotaan dalam organisasi kemasyarakatan pada umumnya bersifat sukarela. Begitu juga dengan kondisi keanggotaan yang ada di PRP Pasundan yang di dominasi oleh masyarakat asli Sukaratu, wacana pembentukan Desa Sukaratu menjadi Desa Wisata dengan sendirinya telah menimbulkan rasa penasaran masyarakat, sehingga PRP tidak memerlukan waktu yang lama untuk dapat merekrut masyarakat yang tertarik bergabung menjadi bagian tim PRP. Hal ini karena memang secara geografis domisili dari masing-masing warga tidak jauh, bahkan masih dalam satu lingkungan sosial dan administrasi yang sama yakni RT/RW.

Bidang-bidang yang ada dalam organisasi dibentuk dengan mempertimbangkan kebutuhan terhadap pengelolaan kegiatan dalam desa wisata. Setiap bidang yang ada di struktur organisasi di isi oleh satu orang yang kemudian diberikan kewenangan untuk menjalankan fungsi tertentu dalam kegiatan wisata dan merekrut orang-orang yang di fungsikan sebagai pelaksana teknis dalam kegiatan wisata yang dilaksanakan. Pola struktur kerja seperti ini dipilih atas dasar pertimbangan perlunya fleksibilitas kepala bidang dalam menjalankan tanggung jawabnya, khususnya dalam membangun tim kerja yang efektif dan sesuai dengan kebutuhan.

Berbagai pihak yang teribat dalam dalam struktur organisasi PRP ini merupakan tokoh yang ada di masyarakat dan orang yang terampil dalam bidang terkait. Pelibatan berbagai pihak ini dilakukan untuk menjaga agar pengembangan desa wisata di Desa Sukaratu mendapatkan dukungan dari masyarakat secara utuh. Pengaruh dari para tokoh ini menjadi pertimbangan dalam pelibatannya, karena dengan pengaruh yang dimilikinya masyarakat akan mudah untuk diajak berpartisipasi dalam kegiatan wisata yang telah direncanakan sebelumnya. Hal ini tidak terlepas dari masih adanya anggapan bahwa masyarakat memandang tokoh masyarakat ini sebagai orang yang memiliki sikap adil dan bisa mewakili kepentingan mereka dibidang kemasyarakatan.

Selain keterlibatan dari masyarakat lokal yang ada di Sukaratu, tim PRP juga melibatkan pihak luar desa. Keterlibatan pihak luar ini di dapat dari Ketua Paguyuban Pasundan Cabang Cianjur yang bernama Abah Rukawan. Kapasitasnya sebagai salah satu tokoh kebudayaan di Kabupaten Cianjur membuat beliau memiliki pengaruh yang cukup besar terhadap berbagai pihak yang ada di dalam pemerintahan Kabupaten Cianjur. Pengaruh dari Abah Rukawan ini mulai banyak dirasakan dan terlihat ketika beliau berhasil mempengaruhi pihak Dinas Pariwisata Kabupaten Cianjur untuk memberikan dukungan kepada masyarakat 
Desa Sukaratu dalam upayanya menjadikan Desa Sukaratu sebagai desa wisata budaya melalui pemanfaatan program PNPM Mandiri Pariwisata.

Walaupun secara kontribusi setiap orangnya berbeda, tapi pihak-pihak yang terlibat dalam tim PRP Pasundan pada dasarnya memiliki hak dan kwajiban yang sama dalam status keanggotaanya. Setiap anggota berhak mendapat uang saku jika ada kegiatan wisata, mengikuti berbagai macam kegiatan yang sifatnya meningkatkan kapasitas dan keterampilan. Kemudian untuk kewajibannya sediri adalah menjalankan semua tugas yang sesuai dengan kemampuan dan keterampilannya bidangnya masingmasing.

\section{b. Sumber Dana}

PRP Pasundan yang didirikan bukan atas dasar sumber financial kuat, tapi kekuatan sosial dan swadaya masyarakat yang masih tinggi membuat berbagai kegiatan yang dilakukan bisa berjalan lancer walaupun dengan biasaya/dana yang minim. Sikap swadaya inilah yang kemudian di dorong untuk terus memperkuat rasa memiliki masyarakat terhadap program dan lembaga yang mengelolnya, karena pada prinsipnya rasa memiliki masyarakat ini yang kemudian membuat lembaga ini tetap kuat dan tetap eksis sampai sekarang. Pada dasarnya pemasukan dana untuk PRP Pasundan sifatnya tidak tetap, karena dalam mekanisme lembaga tidak mengenal iuran anggota yang sifatnya rutin atau berkala. Sumber dana yang bisa dikatakan sebagai pemasukan lembaga lebih banyak di dapat dari jasa pemanduan wisata dengan besaran yang tidak tetap juga.
Dana yang diterima dari kegiatan wisata selanjutnya didistribusikan kedalam berbagai pos. Distribusi tersebut diatur dengan persentase tertentu, yaitu: Pemasukan Kas Desa 10\%, Penghasilan Individu Warga (pemilik objek/fasilitas) 20\%, dan Operasional Manajemen Pelaksana $70 \%$. Besaran pembagian hasil penerimaan dari biaya kunjungan memberikan persentase yang sangat besar bagi operasional manajemen pelaksana karena segala pengadaan dan fasilitasi pelaksanaan wisata dibebankan kepada penerimaan pihak manajemen pelaksana. Warga masyarakat yang terlibat dalam kegiatan desa wisata dapat merasakan langsung adanya penghasilan tambahan yang mereka terima.

Selain pemasukan dari kegiatan layanan wisata PRP juga mendapat bantuan stimulan dari pihak pemerintah dan lembaga swasta. Dalam rangka mendukung program wisata yang ada di desa sukaratu pihak pemerintah cianjur memberikan bantuan penataan lingkungan desa, program bantuan KUBE (Kelompok Usaha Bersama) untuk mendukung kegiatan perekonomian kelompok usaha kecil. Sumber dana financial yang cukup besar juga pernah di terima tim puggawa ratu yang datang dari program PNPM Madiri Pariwisata Kementerian Pariwisata yang distribusinya melalui Dinas Pariwisata Kabupaten Cianjur. Sepanjang penyelenggaraan desa wisata, Tim Pengelola Kegiatan (TPK) Desa Wisata Desa Sukaratu sudah dua kali mendapatkan bantuan. Bantuan yang pertama sebesar Rp. 50 Juta, dipergunakan untuk pembangunan sarana-prasarana pendukung kegiatan pariwisata, yaitu saung pertemuan dan MCK. Bantuan yang kedua sebesar Rp 75 Juta dipergunakan utk membeli alat kesenian dan pakaian 
seragam. Untuk penggunaan dana bantuan yang kedua, fokus kegiatan diarahkan kepada penyediaan alat-alat kesenian beserta pakaian seragam. Kemudian selain itu, bantuan dana yang terhimpun dari berbagai sumber tersebut digunakan untuk membangun sarana pendukung program desa wisata yaitu: Saung (balai pertemuan), membangun MCK, serta pengadaan alat-alat kelengkapan untuk kegiatan desa wisata yaitu beberapa set pakaian seragam kesenian, beberapa perangkat alat kesenian, serta sound system. Sementara itu untuk bantuan peningkatan kapasitas warga masyarakat banyak di dapat dari berbagai jejaring yang dimiliki masyarakat Sukaratu

\section{c. Kegiatan}

Kegiatan yang ada dalam organisasi lokal sangat tergantung kepada komitmen awal dibentuknya organisasi tersebut, artinya berbagai kegiatan yang dilakukan merupakan suatu hasil keputusan yang telah dirumuskan dalam sebuah musyawarah yang dihadiri oleh anggota organisasi. Begitu juga dengan lembaga PRP yang memiliki kegiatan khusus di bidang wisata desa, sehingga identitasnya sebagai lembaga pengelola wisata akan sangat terlihat dari kegiatan yang sering dilakukan.

Dalam rangka memperkuat hubungan internal anggota PRP biasanya melakukan pertemuan seminggu sekali yang bertempat di aula Desa Sukaratu atau di Saung Pasanggrahan dekat rumah pekerja sosial sambil ngaliwet. Pertemuan tersebut dijadikan sebagai wadah untuk membahas berbagai macam kebutuhan kegiatan wisata, keluhan-keluhan selama bergabung di PRP dan hal-hal lain yang terkait dengan rencana kegiatan PRP. Selain petemuan rutin seminggu sekali, lembaga pun tidak jarang melakukan Study banding ke berbagai tempat untuk terus memberikan stimulus kepada anggota agar terus memiliki motivasi untu berfikir kreatif, diantara tempat-tempat yang pernah dikunjungi dalam rangka study banding adalah Komunitas Hong, PRP Cisolok dan PRP Gunung Padang serta PRP Cibodas.

Kegiatan latihan juga setiap minggu sering dilakukan di depan kantor desa sukartu. Kegiatan ini biasanya dilakukan pada sore hari dan bisa sampai malam, selain sebagai wadah untuk mengasah keterampilan, kegiatan ini juga menjadi wadah untuk berinteraksi antara anggota PRP dan masyarakat yang datang untuk menyaksikan langung kegiatan latihan kelompok-kelompok kesenian yang ada di Sukaratu. Kelompok-kelompok tersebut diantaranya :Maenpo, Gendang Penca, Upacara Adat, Kesenian Calung, Kaulinan Barudak.

Kegiatan lain yang berhubungan dengan PRP adalah kegiatan wisata yang di dalamnya terdapat berbagai kegiatan, seperti diantaranya: Jalan Pagi "Mapag Ibun" (cross country), tatanen, dahar ponyo, dulang, boboko, rantang dan lain sebagainya.

\section{d. Jangkauan Wilayah Kegiatan}

Jangkauan wilayah kegiatan PRP banyak dipengaruhi oleh permintaan layanan yang diminta oleh pihak wisatawan ataupun masyarakat pada umumnya, sehingga keterlibatan dari anggota tim dalam satu kegiatan tidak akan sama karena akan disesuaikan dengan kebutuhan kegiatan tersebut. Pada dasarnya kegiatan PRP lebih banyak dilakukan pada ruang lingkup Desa Sukaratu. Hal ini disebabkan oleh faktor layanan wisata dan konsep wisata yang diusung oleh PRP adalah konsep wisata 
yang terpusat dengan memberdayakan segenap potensi yang dimiliki oleh desa dan warga masyarakat lokalnya. Akan tetapi pada moment tertentu kegiatan wisata bisa saja keluar dari wilayah Desa Sukaratu jika ada permintaan dari wisatawan yang menginginkan kegiatan "nyaba" misalnya. Adanya paket "nyaba" ini memungkinkan wisatawan beserta pemandunya keluar desa mengunjungi tempat-tempat yang menarik di sekitar kota Cianjur, seperti alun-alun Cianjur, menjid alun-alun Cianjur, sentra oleh-oleh khas Cianjur dan lain sebagainya.

Sementara itu, selain jangkauan kegiatan dalam bentuk pelayanan wisata kepada wisatawan, anggota yang tergabung dengan PRP juga tidak jarang mengadakan kegiatan atau mengikuti kegiatan pelatihan yang diadakan diluar Desa Sukaratu, seperti pada kegiatan pelatihan kepariwisataan yang diadakan dinas pariwisata di kabupaten pangandaran. Kemudian beberapa kelompok yang tergabung di dalam PRP juga tidak jarang menerima undangan tampil mengisi berbagai acara yang lokasinya berada diluar Desa Sukaratu, salah satu diantaranya adalah kelompok gendang penca dan calung yang pernah tampil sampai ke daerah yang berada di Kabupaten Sukabumi.

\section{e. Sistem Jaringan Kerja}

Sebuah organisasi pada dasarnya sangat terbuka terhadap berbagai jalinan kerjasama dengan berbagai pihak. Apalagi kerjasama yang dimaksud adalah kerjasama yang dapat memberikan keuntungan bagi lembaga dan para penerima manfaat layanan yang diberikan oleh lembaga. Begitu juga dengan apa yang dilakukan oleh PRP sebagai lembaga pengelola wisata Desa Sukartu, jalinan kerjasama dengan berbagai pihak banyak dilakukan guna mendukung terselenggaranya kegiatan wisata yang dapat memberikan keuntungan bagi masyarakat Desa Sukaratu.

Jaringan kerjasama yang dibangun oleh tim PRP dengan kelompok-kelompok yang menjadi penggerak pariwisata di Sukaratu menjadi salalsatu modal kerjasama yang sampai saat ini masih dipertahankan. Kesiapan mereka untuk ikut terlibat dalam segala aktivitas wisata menjadi salah satu bentuk komitmen kerjasama yang berhasil dibangun oleh tim punggawaratu. Jalinan kerjasama lain yang dilakukan oleh PRP adalah dengan pihak pemerintah, seperti dinas pariwisata dan dinas sosial. Bentuk kerjasama yang dibangun adalah kemudahan akses bantuan melalui berbagai program pemerintah yang bisa di integrasikan dengan program Desa Wisata yang telah dijalankan di Desa Sukaratu. Kemudian kerjasma juga dibangun dengan lembaga-lembaga yang konsen terhadap isu pelestarian budaya dan pemberdayaan masyarakat, lembaga yang dimaksud diantaranya paguyuban pasundan cabang Cianjur, Yayasan Usaha Mulia (YUM), YPM Kesuma. Selain dengan lembaga, PRP juga melakukan kerjasama dengan para akademisi yang ada di perguruan tinggi yang ada di Bandung, seperti diantaranya : Sekolah Tinggi Kesejahteraan Sosial Bandung, Universitas Pasundan, Universitas Pendidikan Indonesia (UPI), Sekolah Tinggi Pariwisata (STIPAR) Bandung. Bentuk kerjasama yang dilakukan lebih banyak kepada peningkatan kapasitas warga masyarakat Sukaratu melalui berbagai macam pelatihan, seperti diantaranya: pelatihan pariwisata dan kewirausahaan. Kerjasama dengan Koran Radar Cianjur juga dilakukan oleh PRP. Dalam hal ini 
PRP sadar akan potensi media yang bisa membantu dalam promosi wisata desa dan publikasi kegiatan wisata yang ada di Sukaratu.

\section{Peran Punggawa Ratu Pasundan Dalam Pengembangan Masyarakat}

PRP adalah institusi lokal di Desa Sukaratu yang menjadi penggerak pembangunan melalui kegiatan wisata lokal. Peluang untuk berkontribusi dalam institusi lokal ini cukup terbuka, karena setiap orang diberikan kebebasan untuk memberikan pengaruhnya dengan keterampilan yang dimilikinya masing-masing. Hal ini dilakukan karena banyaknya keterampilan yang dimiliki anggotanya untuk mendukung kegiatan wisata di Sukaratu, sehingga mereka perlu diberikan ruang untuk berkreasi mewujudkan ide-idenya agar peranan PRP dalam pembangunan di masyarakat dapat terlihat pengaruhnya. Berikut beberapa peranan yang telah dilakukan oleh lembaga PRP dalam mendukung kegiatan pengembangan masyarakat melalui program desa wisata.

\section{a. Fasilitatif}

Peran fasilitatif merupakan salah satu peran yang penting dilakukan oleh sebuah organisasi, hal ini dilakukan dalam rangka proses pengembangan masyarakat yang dilakukan melalui program desa wisata. Peran ini dilakukan untuk mempermudah proses perubahan perilaku dari individu atau kelompok masyarakat dengan menyediakan berbagai macam kebutuhannya, baik waktu, pemikiran dan sarana lain yang dibutuhkan oleh masyarakat. PRP dengan kapasitasnya sebagai pengelola wisata di Desa Sukaratu, pada prinsipnya harus dapat mewadahi berbagai macam potensi yang dimiliki desa dan masyarakatnya, karena tidak dipungkiri banyaknya anggota yang ada di dalamnya memiliki berbagai macam kepentingan, sehingga sangatlah penting bagi PRP menyatukan berbagai macam kepentingan tersebut menjadi suatu tujuan bersama yang dapat mengakomodir kebutuhan anggotanya.

Dalam rangka mengakomodir kebutuhan masyarakat ini PRP menyelenggarakan berbagai kegiatan yang sifatnya memfasilitasi berbagai kebutuhan dan pengembangan potensi yang dimiliki oleh masyarakat. Kegiatan-kegiatan tersebut diantaeranya : pemetaan potensi dan kebutuhan masyarakat melalui kegiatan diskusi dan study banding ke beberapa tempat wisata agar masyarakat dapat belajar dan terinspirasi dengan kegiatan kegiatan wisata yang telah dilakukan tempat wisata lain. Selain itu kegiatan pelatihan juga tidak jarang dilakukan oleh tim PRP guna meningkatkan kapasitas anggota PRP dan masyarakat Sukaratu. Kemudian untuk kegiatan lain PRP juga memfasilitasi segala bentuk kebutuhan warga, misalnya ketika warga menginginkan hiburan tradisonal dalam satu kegiatan, maka PRP akan hadir dengan kelompokkelompok kesenian tradisionalnya seperti: kendang penca, calung, upacara adat pernikahan, tari jaipong dan lain sebagainya.

\section{b. Mediasi}

Peran sebagai mediator sangat diperlukan oleh sebuah organisasi terutama pada saat terdapat perbdaan 
yang mencolok dan mengarah kepada konflik antar berbagai pihak yang ada dalam organisasi dan luar organisasi. Upaya-upaya yang dilakukan oleh organisasi pada hakikatnya diarahkan untuk mencapai solusi yang baik atau win-win solution. Peran PRP sebagai mediator dalam konflik-konflik yang ada di Sukaratu tidak banyak dilakukan khususnya untuk konflik yang ada masyarakat, hal ini karena mekanisme penyelesaian konflik yang ada di masyarakat masih berjalan dengan baik, sehingga tidak banyak konflik yang mencuat ke permukaan dan menjadi perhatian dari banyak orang.

Adapun konflik yang banyak terjadi dan dibantu oleh PRP adalah konflik yang terjadi di dalam tubuh organisasi PRP sendiri, misalnya konflik yang terjadi ketika adanya program bantuan dari pemerintah melalui program PNPM Mandiri Pariwisata. Isu konflik yang muncul ke permukaan adalah transparansi penggunaan anggaran dan ketidak merataan bantuan yang diberikan kepada kelompok-kelompok yang tergabung dalam PRP. Namun hal itu berhasil diselesaikan dengan upaya memfasilitasi kelompok-kelompok untuk dapat berkomunikasi dan berbicara satu sama lain. Melalui proses fasilitasi inilah berbagai masalah yang muncul di dalam tubuh organisasi selalu dapat dinetralkan dengan proses musyawarah

\section{c. Penyampai Informasi}

Informasi menjadi suatu hal yang krusial dalam membangun kekompakan anggota dalam sebuah tim kerja. Begitu juga dengan yang dilakukan oleh PRP sebagai organisasi lokal yang memiliki banyak sekali anggota dari berbagai kelompok penggerak pariwisata di Desa Sukaratu. Kegiatan berkumpul seperti rapat mingguan menjadi salah satu wadah untuk menyampaikan berbagai macam informasi, baik yang terkait dengan informasi kunjungan dari wisatawan ataupun informasi perkembangan keadaan lembaga PRP.

Setiap anggota yang terlibat dalam kegiatan rapat tersebut pada dasarnya merupakan kepanjangan lidah dari PRP itu sendiri. Mereka memiliki tanggung jawab untuk menyampaikan segala bentuk informasi yang menyangkut kepentingan umum kepada warga atau anggota yang berhalangan hadir saat itu. Adapun kebijakan lain, ada beberapa informasi yang memang tidak harus disampaikan secara luas ke masyarakat. PRP memiliki mekanisme sendiri untuk memilah dan memilah informasi mana yang masyarakat perlu tahu dan informasi mana yang masyarakat tidak perlu tahu. Hal ini dilakukan bukan berarti mengajarkan masyarakat untuk tidak transparan terhadap suatu kondisi, melainkan ada pertimbangan tujuan agar masyarakat tidak kebingungan terhadap informasi yang disampaikan dengan aktivitas yang akan dilaksanakan dilapangan. Misalkan tentang informasi perbedaan pendapat dalam konsep penyambutan wisatawan, perbedaan yang ada tidak di expose keluar namum kesepakan bersamalah yang kemudian di sosialisasikan kepada masyarakat luas.

Sumber informasi yang biasa disampaikan dalam kegiatan biasanya datang dari wisatawan melalui saluran telphone, sms, ataupun email. PRP 
sendiri pun mendapatkan informasi yaitu dari tokoh-tokoh masyarakat Desa Sukaratu, selain itu informasi yang didapat dari PRP pun berasal dari internet. Selain tokoh masyarakat dan internet, PRP pun mendapatkan informasi dari pihak-pihak yang berkepentingan terhadap berjalannya PRP ini, misalnya dari Dinas Kebudayaan dan Pariwisata sebagai dinas terkait dalam hal kebudayaan dan pariwisata. Sekolah dan universitas pun menjadi sumber informasi bagi PRP, dimana sekolah dan universitas merupakan salah satu sarana untuk mendatangkan wisatawan ke Desa Sukaratu. Dengan mendatangkan banyak wisatawan ke desa Sukaratu akan memberikan manfaat bagi Desa Sukaratu sendiri sehingga wisatawisata yang ada akan dikenal oleh wisatawan yang datang.

PRP sebagai sebuah institusi lokal, menjembatani masyarakat dalam mengakses informasi yang ada. Informasi-informasi yang ada dihimpun oleh PRP yang kemudian disebarluaskan atau disampaikan kepada masyarakat. Adanya PRP ini cukup efektif, karena ada proses edukasi yang terus berjalan kepada masyarakat, sepertihalnya masyarakat yang awalnya tidak tahu menahu tentang informasi kebudayaan dan pariwisata dan lainnya melalui adanya PRP ini masyarakat menjadi tahu. Dengan demikian adanya PRP ini memberikan warna baru di masyarakat dalam bidang pemberian wawasan dan informasi, sehingga kapasitas masyarakat akan terus bertambah seiring banyaknya informasi yang masuk ke masyarakat.

\section{d. Pendayaguanaan Gotong royong}

Pada sebuah institusi lokal seperti PRP ini mendayagunakan gotong royong sangat beguna sebagai salah satu cara untuk menjaga kebersamaan anggota, menumbuhkan rasa persatuan antar anggota untuk saling bekerja sama. Gotong royong merupakan semangat yang diwujudkan melalui perilaku yang kemudian tidak mengharapkan adanya imbalan apapun. PRP sebagai sebuah institusi lokal memanfaatkan gotong royong sebagai salah satu cara untuk menjaga eksistensi lembaga secara internal, mempererat hubungan antar anggota dan menjadikan masyarakat semakin kompak. Melalui gotong royong akan tumbuh rasa kerja sama baik dalam lingkup anggota maupun dengan masyarakat yang bukan anggota dari PRP tersebut. Bentuk gotong royong yang dilakukan adalah adanya jumsih (jum'at bersih), yaitu kegiatan gotong royong membersihkan mesjid bersama anggota DKM. Strategi yang digunakan untuk menarik minat masyarakat agar ingin mengikuti gotong royong adalah dengan cara melibatkan kepala desa dan anggotaanggota PRP.

\section{Manfaat Keberadaan Punggawa Ratu Pasundan}

Keberadaan PRP sebagai institusi lokal dalam pengembangan desa wisata di Desa Sukaratu memiliki implikasi yang cukup luas dalam kehidupan masyarakat dan mencakup bebrbagai aspek. Manfaat yang dirasakan setidaknya meliputi manfaat sosial, budaya, dan ekonomi. 


\section{a. Manfaat Sosial}

Sebelum adanya PRP masyarakat "tercecer", artinya tidak ada sesuatu yang menyatukan mereka. Melalui adanya PRP ini sebagai wadah untuk menyatukan masyarakat. Dengan adanya PRP ini sebagai pemersatu antar masyarakat sehingga menjadikan masyarakat menjadi lebih kompak dan menjadikan interaksi antar warga pun menjadi lebih erat.

Selain itu adanya PRP ini menjadikan masyarakat Desa Sukaratu menjadi lebih percaya diri baik di lingkungan Desa Sukaratu sendiri maupun ketika berinteraksi dengan masyarakat Desa lain. Hal ini dikarenakan masyarakat Desa Sukaratu mempunyai sesuatu yang lebih yang tidak dimiliki oleh masyarakat desa lain. Sehingga hal ini menjadi nilai tambah bagi masyarakat Desa Sukaratu.

\section{b. Manfaat Budaya}

Dalam segi budaya, Desa Sukaratu memang kaya akan budaya. Jika tidak dilestarikan maka dikhawatirkan budaya-budaya yang ada tersebut akan punah. Dengan adanya PRP ini sebagai wadah untuk melestarikan kebudayaan yang ada di Desa Sukaratu. PRP sebagai sebuah institusi lokal mewadahi berbagai kebudayaan yang ada di Desa Sukaratu, untuk melestarikan kebudayaan tersebut yaitu dibentuk kelompok-kelompok kecil yang didalamnya terdiri dari beberapa anggota. Kelompok tersebut dibuat berdasarkan keahlian masingmasing masyarakat. Selanjutnya adanya pembentukan kelompok ini adalah untuk mempermudah pemaksimalan potensi masyakat Desa Sukaratu.

\section{c. Manfaat Ekonomi}

Masyarakat Desa Sukaratu pada umumnya bermata pencaharian sebagai petani. Sedangkan untuk ibuibunya mayoritas adalah sebagai ibu rumah tangga. Keinginan masyarakat dari segi ekonomi adalah adanya penghasilan tambahan bagi keluarga. Adanya PRP sebagai sebuah institusi lokal ini tentu memberikan manfaat kepada masyarakat, termasuk dalam segi ekonomi. Adanya wisatawan yang datang ke Desa Sukaratu merupakan salah satu kesempatan masyarakat untuk dapat menambah penghasilan bagi masyarakat Desa Sukaratu, misalnya dari kelompok kuliner membuat oleh-oleh khas Desa Sukaratu selanjutnya ditawarkan kepada wisatawan yang datang ke Desa Sukaratu. Sampai saat ini banyak wisatawan yang tertarik akan oleh-oleh yang dibuat oleh masyarakat Desa Sukaratu. Oleh-oleh tersebut berupa olahan jambu, jus jambu, raginang, kicimpring dan lain sebagainya. Selain itu, wisatawan yang datang pun membutuhkan tempat penginapan. Penginapan yang disediakan yaitu merupakan rumah warga yang kondisinya layak. Memang masyarakat tidak memberikan patokan harga untuk penginapan. Namun hal tersebut memberikan manfaat kepada masyarakat yang menyediakan penginapan.

\section{SIMPULAN}

Aktivitas kegiatan pengembangan yang dilakukan oleh PRP pada dasarnya adalah bentuk implementasi dari perananan yang dimilikinya. Berdasarkan hasil penelitian yang telah 
dilakukan, PRP telah melakukan empat peran yang mendukung kepada proses pengembangan masyarakat yang dilakukan di Desa Sukaratu melalui program desa wisata, yakni: peran fasilitatif, mediasi, penyampai informasi dan pendayagunaan gotong royong. Adapun masalah yang sedang dihadapi PRP sekarang adalah hilangnya salah satu sosok tokoh masyarakat. Kehilangan ini berdampak kepada tidak adanya penggerak yang memiliki semangat melestarikan budaya dan seni melalui kegiatankegiatan wisata yang ada di Desa Sukaratu. Selain itu, sejak adanya pembaharuan kepengurusan, surat keputusan untuk kepengurusan yang baru belum diterbitkan oleh pemerintah Desa Sukaratu membuat anggota PRP kurang mendapatkan pengauatan dalam bergerak, sehingga menurunkansemangat mereka dalam melanjutkan kegiatan-kegiatan wisata desa dalam rangka pembangunan desa.

\section{DAFTAR PUSTAKA}

Botes, Lucius \& Rensburg, Dingie van. 2000. "Community Participation In

Development: Nine Plagues And Twelve Commandments". Community Development Journal, 35 (1), hal 41-58

Breugel, Liedewij van. 2013. Communitybased tourism Local participation and perceived impacts: A comparative study between two communities in Thailand. Master Thesis. Radboud University Nijmegen

Buccus, Imraan; Hemson, David; Hicks, Janine; dan Piper, Laurence. 2008. "Community Development And
Engagement With Local Governance in South Africa".Community Development Journal, 43 (3): 297-311

Creswell, John W. 2002. Desain Penelitian: Pendekatan Kualitatif dan Kuantitatif. Jakarta : KIK Press

Eversole, Robyn. 2012. "Remaking Participation: Challenges For Community Development Practice", Community Development Journal,47 (1), hal 29-41

Fairchild. 1980. Dictionary of Sociology. New Jersey: Little field Adam \& Co.

Marfo, Emmanuel. 2008. "Institutionalizing Citizen Participation And Community Representation In Natural Resource Management: Lessons From The Social Responsibility Agreement Negotiation In Ghana". Community Development Journal, 43 (4), hal 398-412

McKinlay, Peter. 2006. "The Challenge Of Democratic Participation In The Community Development Process". Community Development Journal, 41 (4), hal 492-505

Miles, Mathew B dan Huberman, Michael. 1985. Analisis Data Kualitatif. Jakarta: Universitas Indonesia Press

Mowbray, Martin. 2011. "What Became Of The Local State? Neo-Liberalism, Community Development And Local Government”. Community Develeopment Journal, 46 (suppl 1), hal i132-i153

Mubyarto. 1998. Gerakan Penanggulangan Kemiskinan, Yogyakarta, Aditya Media

Putra, Theofilus Retmana. 2013. Peran Pokdarwis dalam Pengembangan 
Atraksi Wisata di Desa Wisata Tembi, Kecamatan Sewon-Kabupaten Bantul. Biro Penerbit Planologi Undip Volume 9 (3): 225-235 September 2013

Uphoff, N. 1986. Local Institutional Development. West Hartford. CT. Kumarian Press

Widodo, Nurdin. 2011. Profil dan peranan organisasi lokal dalam Pembangunan masyarakat. Sosiokonsepsia, Vol. 16 No. 02, Tahun 2011

Yen, Ngo Thi Kim \& Luong, Pham Van. 2008. "Participatory Village And Commune Development Planning (VDP/CDP) And Its Contribution To Local Community Development In Vietnam". Community Development Journal, 43 (3), hal 329340 